Ewa MYŚLAK

Uniwersytet Jagielloński, Kraków

\title{
Narodowy Bank Polski wobec transformacji ustrojowej: pozycja prawna - organizacja - funkcje
}

Transformacja ustrojowa w Polsce, która rozpoczęła się w latach 80 . Zmiany te dotyczyły zarówno ustroju politycznego, społecznego jak i gospodarczego. Bank centralny jest instytucją silnie związaną z funkcjonowaniem gospodarki, a w szczególności z jedną z jej dziedzin: polityką pieniężną. Warunki gospodarki centralnie planowanej stawiały przed bankiem centralnym odmienne wyzwania niż następujące w wyniku przemian demokratycznych realia gospodarki wolnorynkowej. Status i zadania Narodowego Banku Polskiego, który pełnił funkcję centralnego banku państwa od 1945 r., podlegały podobnej ewolucji, jak pozostałe elementy ustroju państwa, zarówno w aspekcie wewnętrznej organizacji, kompetencji, jak również relacji z pozostałymi organami państwowymi. Wraz ze zmianą ustrojową stworzony został w Polsce nowy model bankowości. To model dwustopniowy, w którym funkcjonują NBP jako centralny bank państwa oraz banki komercyjne. Celem artykułu jest przedstawienie zmian w pozycji prawnej, ustrojowej, kompetencjach i funkcjach oraz strukturze organizacyjnej NBP od początków jego istnienia, aż do obecnych rozwiązań prawnych opartych o przepisy Konstytucji Rzeczypospolitej Polskiej z 2 kwietnia 1997 r. oraz ustawy o Narodowym Banku Polskim z 29 sierpnia $1997 \mathrm{r}$.

\section{Pozycja prawna i ustrojowa Narodowego Banku Polskiego}

Zasadniczą zmianą w usytuowaniu regulacji prawnych dotyczących problematyki bankowości centralnej jest poświęcenie jej nie tylko konkretnej ustawy, ale - co zasługuje na szczególną uwagę - przepisów ustawy zasadniczej. Narodowy Bank Polski do tej pory funkcjonował głównie w oparciu o ustawową regulację, a w okresie powojennym o dekret wydany przez rząd. Konstytucja Rzeczypospolitej Polskiej z 2 kwietnia 1997 r. 
wprowadziła nową jakość do funkcjonowania Narodowego Banku Polskiego. Oprócz wskazywanego już podniesienia rangi banku centralnego do konstytucyjnego organu państwa, dokonano zasadniczej zmiany merytorycznej, wpisując w art. 227 ust. 1 Konstytucji, iż NBP jako centralnemu bankowi państwa przysługuje wyłączne prawo emisji pieniądza oraz ustalania i realizowania polityki pieniężnej. W ten sposób Sejm oraz organy władzy wykonawczej zostały pozbawione formalnego wpływu na kwestię określania założeń polityki pieniężnej. Przepis ten wraz z treścią art. 220 ust. 2 Konstytucji, który stwierdza, iż ustawa budżetowa nie może przewidywać pokrywania deficytu budżetowego przez zaciaganie zobowiązania w centralnym banku państwa ${ }^{1}$, stanowi istotną zmianę w niezależności NBP. Następstwami powyższych zmian było zredefiniowanie zasad kierowania bankiem centralnym: dotychczasowa formuła jednoosobowego kierownictwa została zmieniona na kolegialne podejmowanie decyzji. Art. 227 Konstytucji ustanawia trzy organy NBP. Są nimi: Prezes NBP, Rada Polityki Pieniężnej, jako zupełnie nowe ciało, i Zarząd NBP. Można stwierdzić, iż Konstytucja w jednym artykule przesądziła o kształcie polskiego banku centralnego i jego podstawowych zadaniach (Niemierka, 1998, s. 7-8). W literaturze przedmiotu spotkać można stanowisko, iż ustawa zasadnicza zbyt szczegółowo potraktowała przepisy o NBP w punktach wyodrębniających organy NBP oraz określających ich funkcje. Zdaniem autorów takie rozwiązanie może powodować trudności w dokonaniu poważniejszej zmiany w funkcjonowaniu NBP oraz zachęcać do kwestionowania treści nowej ustawy o NBP (por. Kosikowski, 1997, s. 161; Niemierka, 1998, s. 8). W rozwiązaniu tym jednak wyraźnie widać zamiar ustrojodawcy zapewnienia stabilnego oraz niezależnego od zmieniających się sił politycznych w państwie funkcjonowania banku poprzez umieszczenie podstaw prawnych jego działania w ustawie zasadniczej. Dopełnieniem przepisów konstytucji jest ustawa o Narodowym Banku Polskim z dnia 29 sierpnia 1997 r. Zawiera ona przepisy określające w sposób szczegółowy organizację i zasady działania banku, tryb powoływania i odwoływania jego organów, funkcje i kompetencje przysługujące NBP oraz jego organom. W pierwszej kolejności jednak ustawa wskazuje na rolę NBP jako banku centralnego Rzeczypospolitej Polskiej i podkreśla, iż podstawowym celem jego działalności jest utrzymanie sta-

Art. 240 Konstytucji przewidywał, że w ciąu roku od dnia wejścia w życie Konstytucji, ustawa budżetowa mogła pokrywać deficyt budżetowy przez zaciaganie zobowiązań w NBP. 
bilnego poziomu cen, przy jednoczesnym wspieraniu polityki gospodarczej rządu, jeśli nie ogranicza to jego podstawowego celu.

\section{Dylematy związane z charakterem prawnym banku państwowego}

Zagadnieniem, co do którego badacze przedmiotu nie są zgodni, jest charakter prawny NBP jako podmiotu prawa. Kluczową kwestią zdaje się być odpowiedź na pytanie czy NBP bądź jego organy: Prezes, RPP lub Zarząd mogą być uznane za organy państwa.

Rozważania nad tym zagadnieniem warto rozpocząć od najbardziej skrajnej tezy co do pozycji NBP w państwie. Cezary Kosikowski, próbując ustalić czym jest Narodowy Bank Polski, wyklucza najpierw, iż jest on przedsiębiorstwem państwowym, bankiem państwowym w rozumieniu ustawy Prawo bankowe oraz organem administracji publicznej. NBP nie jest również organem naczelnym bądź centralnym, ponieważ prowadzi samodzielną gospodarkę finansową i nie jest dysponentem części budżetowej $\mathrm{w}$ budżecie państwa, gdzie budżetowe finansowanie jest charakterystyczne dla tego typu podmiotów. Zdaniem Kosikowskiego NBP jest bowiem centralnym bankiem państwa, co rozumieć należy jako sytuację odrębną od innych banków i od innych podmiotów prawnych, niedającą podstaw do porównywania pozycji NBP z innymi podmiotami (Kosikowski, 2002, s. 20-21).

$\mathrm{Z}$ argumentacją o innym charakterze można zapoznać się w artykule autorstwa Marka Zubika (Zubik, 2001, s. 35). Badacz stoi na stanowisku, iż na gruncie obecnych przepisów konstytucyjnych i ustawowych, NBP nie jest organem państwa, natomiast broni tezy, iż organy NBP: RPP, Prezes oraz Zarząd są organami państwa. Swoją tezę buduje na definicji organu państwa jako podmiotu, który został ustanowiony przez prawo, i z mocy prawa wyposażony w jemu właściwe kompetencje do władczego działania w imieniu i na rzecz państwa. Aby uznać dany podmiot za organ państwowy łącznie prawo stanowione musi wyodrębnić elementy takie jak: podstawy organizacyjne (zasady powoływania, uzupełniania składu i odwoływania), zasady działania (formy i tryb realizacji władczych działań) oraz szczegółowy zakres kompetencji każdego organu. Mimo iż konstytucja normatywnie wyodrębniła NBP to trudności według badacza napotyka oznaczenie piastunów takiego „organu państwa”. Przede wszystkim, dlatego że NBP jest bankiem, a taka struktura organizacyjna wymaga dopiero wskazania tych organów, których działanie będzie mogło być rozumiane, w świetle prawa, jako wyraz woli samej instytucji. Natomiast 
konstytucyjnie wyodrębnione organy NBP - Prezes, RPP i Zarząd - mogą być uznane za organy państwa. Wszystkie te podmioty zostały wykreowane przez prawo, prawo określa ich skład osobowy i, co najważniejsze, posiadają tylko sobie właściwe kompetencje do władczego działania w imieniu i na rzecz państwa. W ten sposób organy banku państwowego wyrażają wolę państwa w ściśle określonych sprawach: RPP - ustalając założenia polityki pieniężnej, Prezes NBP - np. wycofując z obiegu znaki pieniężne, czy Zarząd - mający wiele kompetencji związanych instrumentami polityki pieniężnej.

Odrębne stanowisko na temat pozycji NBP w państwie przedstawia w swych rozważaniach Remigiusz Witold Kaszubski (Kaszubski, 1995a, s. 2-5). Odwołując się do orzeczenia Trybunału Konstytucyjnego z 13 września 1990 roku wydanego w związku z aktami prawnymi wydawanymi przez Prezesa NBP stoi on na pozycji uznania NBP za centralny organ państwa. W uzasadnieniu TK stwierdził, że art. 1 ustawy o NBP wyraźnie stanowi, iż NBP jest centralnym bankiem państwa, a zatem przepis ten przesądza o jego charakterze jako centralnego organu państwa. (Trybunał odnosił się wówczas do ustawy o NBP z 1989 r. którego art. 1 brzmiał „Narodowy Bank Polski [...] jest centralnym bankiem państwa”, jednak zarówno art. 1 ustawy z 1997 roku oraz art. 227 ust. 1 Konstytucji powtarzają ten przepis). Określenie „centralny organ państwa” w stosunku do NBP jest w takim razie uwarunkowany konstytucyjnie i ustawowo funkcjami i kompetencjami, jakie spełnia będąc „,centralnym bankiem państwa" niezależnym od naczelnych organów administracji państwowej.

Do tezy, iż NBP możemy uznać za organ państwa przekonuje również późniejsze orzecznictwo Trybunału Konstytucyjnego. W wyroku z 26 maja 1998 r. (K. 17/98), TK przyjął, iż do uznania danego organu za „konstytucyjny organ państwa" konieczne jest, aby bezpośrednio na gruncie samych przepisów Konstytucji spełniony został co najmniej jeden z warunków: w tekście ustawy zasadniczej wymieniona została nazwa tego organu, określony został sposób jego utworzenia bądź wyodrębnienia jego struktury organizacyjnej, przesądzono kwestie jego kadencyjności, przyznane mu zostały wyraźnie określone kompetencje, bądź nastąpiło określenie relacji między tym organem władzy a innymi organami państwa (Zubik, 2001, s. 36-37). W odniesieniu do Narodowego Banku Polskiego przepisy konstytucji obejmują wszystkie powyższe punkty:

1) nazwa centralnego banku państwa pojawia się w kilku artykułach ustawy zasadniczej m.in. w artykule 227 ustęp 1: „centralnym bankiem państwa jest Narodowy Bank Polski”; 
2) struktura organizacyjna banku przedstawiona jest w artykule 227 ustęp 2 poprzez wymienienie jego organów (Prezes NBP, Rada Polityki Pieniężnej oraz Zarząd NBP). W dalszej części artykuł ten określa kadencyjność i sposób wyboru Prezesa oraz Rady Polityki Pieniężnej;

3) kompetencje NBP są sprecyzowane w ustępie 1 art. 227, który stanowi, iż Narodowemu Bankowi Polskiemu ,przysługuje wyłączne prawo emisji pieniądza oraz ustalania i realizowania polityki pieniężnej”;

4) przepisy określające relacje między NBP a innymi organami państwowymi znajdują się w: artykule 227 ustęp 6, który nakłada na Radę Polityki Pieniężnej obowiązek przedłożenia do wiadomości Sejmowi corocznych założeń polityki pieniężnej oraz złożenia sprawozdania z wykonania założeń polityki pieniężnej; artykule 198 ustęp 1, który stanowi, iż Prezes Narodowego Banku Polskiego za naruszenie konstytucji lub ustawy, w związku z zajmowanym stanowiskiem lub w zakresie swojego urzędowania, ponosi odpowiedzialność konstytucyjną przed Trybunałem Stanu; artykule 203 ustęp 1, który ustanawia, iż „Najwyższa Izba Kontroli kontroluje działalność [...] Narodowego Banku Polskiego z punktu widzenia legalności, gospodarności, celowości i rzetelności”.

Na podstawie wyżej przedstawionej przepisów konstytucji, możemy wnioskować, iż NBP spełnia wszystkie warunki, wymagane przez Trybunał Konstytucyjny w wyroku z 26 maja 1998 r., dla uznania danego organu za „konstytucyjny organ państwa”. Na tej podstawie usankcjonowanym jest przyznanie Narodowemu Bankowi Polskiemu statusu konstytucyjnego organu państwa.

\section{Organy polskiego banku centralnego w latach 1945-1997}

Narodowy Bank Polski rozpoczął swoje funkcjonowanie na podstawie dekretu z 15 stycznia 1945 r. Naczelnym organem władz NBP była wtedy Rada Banku, która nadawała i kontrolowała ogólny kierunek działalności banku oraz sprawowała nadzór nad czynnościami jego organów wykonawczych. Członków Rady Banku powoływała Rada Ministrów na wniosek ministra skarbu. Prezes Narodowego Banku Polskiego, który przewodniczył Radzie, mianowany był przez prezydenta państwa. Do jego głównych zadań należało sprawowanie funkcji kierowniczych oraz kontrolowanie uchwał Rady. Nowym organem banku był Zarząd składający się z naczelnego dyrektora, którego głównym zadaniem była działalność organizacyj- 
na i administracyjno-techniczna, oraz dwóch zastępców. Zarząd według statutu miał być wybierany przez Radę, a w rzeczywistości powoływał go rząd. Jego głównym zadaniem było techniczne kierownictwo banku oraz załatwianie spraw nie zastrzeżonych innym organom (Kaszubski, 1995b, s. 11; Jezierski, Leszczyńska, 1996, s. 16-18).

Dalsze zmiany w organizacji NBP, znacznie głębsze, zostały dokonane ustawą o NBP z 2 grudnia 1958 r. Na mocy tej ustawy władze Banku tworzyli Prezes, Zarząd i Rada Banku. Organem ustawodawczym został Zarząd, składający się z Prezesa, wiceprezesów - powoływanych przez Prezesa Rady Ministrów na wniosek ministra finansów po uzgodnieniu z Prezesem banku - oraz innych członków powoływanych przez ministra finansów na wniosek Prezesa banku. Prezes banku kierował działalnością NBP zgodnie z wytycznymi ministra finansów i na podstawie uchwał Zarządu. Był on powoływany przez Radę Ministrów na wniosek Prezesa Rady Ministrów. Organem doradczym Zarządu była Rada Banku, do której zadań należało rozpatrywanie spraw z zakresu podstawowej działalności banku, z uwzględnieniem interesów poszczególnych dziedzin gospodarki narodowej oraz zapewnienie ściślejszego powiązania pracy banku z potrzebami gospodarki narodowej. Charakter Rady Banku został całkowicie zmieniony w stosunku do regulacji z okresu międzywojennego i powojennego. W skład Rady Banku wchodzili: Prezes banku jako przewodniczący oraz członkowie wybierani spośród działaczy gospodarczych, wybitnych znawców różnych dziedzin gospodarki i pracowników nauki. Byli oni powoływani przez Prezesa Rady Ministrów na wniosek ministra finansów po uzgodnieniu z Prezesem banku. W rozwiązaniach prawnych opartych na ustawie z 1958 r. nadal można było mówić o kolegialnym kierowaniu bankiem przez Zarząd (Gronkiewicz-Waltz, 1994, s. 103-104; Jezierski, Leszczyńska, 2001, s. 52-54).

Zasada kolegialności w zarządzaniu bankiem centralnym przestała obowiązywać w roku 1975. Od tego momentu organem zarządzającym stał się Prezes. Ustawa z 12 czerwca 1975 r. - o prawie bankowym - wprowadziła zasadę jednoosobowego kierownictwa. Na czele NBP stał Prezes powoływany przez Radę Ministrów, na wniosek Prezesa Rady Ministrów. Prezes NBP kierował działalnością banku, zgodnie z wytycznymi ministra finansów (Gronkiewicz-Waltz, 1994, s. 103-104). W skład Zarządu wchodzili Prezes, wiceprezesi oraz inni członkowie zarządu. Wiceprezesów NBP powoływał Prezes Rady Ministrów na wniosek ministra finansów po uzgodnieniu z Prezesem NBP, a pozostałych członków zarządu - minister finansów na wniosek Prezesa NBP. Szczegółowe przepisy doty- 
czące organizacji NBP zostały zawarte w Statucie banku z dnia 27 czerwca 1975 r. Powtórzono w nim zasadę jednoosobowego kierownictwa bankiem przez Prezesa NBP wymieniając między innymi takie jego funkcje jak: nadzór nad prawidłową realizacją zadań NBP, kierowanie pracami Zarządu NBP czy pełnienie funkcji przełożonego wszystkich pracowników NBP. W celu realizacji swoich kompetencji Prezes został wyposażony w prawo do wydawania zarządzeń wewnętrznych, instrukcji, regulaminów i innych przepisów regulujących działalność i organizację NBP. Do zadań Zarządu NBP natomiast zostało przydzielone rozpatrywanie głównych zagadnień z zakresu działalności NBP w szczególności dotyczących m.in. planów kredytowego i kasowego oraz bilansu płatniczego państwa, systemu kredytowego, pieniężnego i rozliczeń czy projektów podstawowych aktów normatywnych dotyczących działalności NBP oraz zarządzeń wewnętrznych, regulaminów i innych przepisów regulujących działalność NBP.

Zasada jednoosobowego kierownictwa bankiem została nadal zachowana $\mathrm{w}$ reformie bankowości przeprowadzonej ustawą o prawie bankowym oraz ustawą o statucie NBP z 1982 roku. Na czele Banku stał Prezes, zarządzający na zasadzie jednoosobowego kierownictwa, powoływany przez Sejm na wniosek Prezesa Rady Ministrów. Jest to znacząca zmiana w stosunku do poprzednich rozwiązań prawnych, w szczególności, iż tryb powoływania i odwoływania Prezesa NBP był trybem przewidzianym dla ministrów i kierowników urzędów centralnych. Prezesowi NBP zagwarantowano ustawowo prawo udziału w posiedzeniach Rady Ministrów oraz wyposażono go w prawo wydawania zarządzeń w granicach upoważnień zawartych w ustawie. Pozycja Prezesa NBP wzmocniła się dzięki pozbawieniu ministra finansów kompetencji w dziedzinie bankowości i systemu pieniężno-kredytowego. Do zadań prezesa NBP należały w szczególności: nadzór nad prawidłową realizacją zadań NBP, kierowanie pracami Zarządu NBP, który był organem pomocniczym Prezesa, samodzielne reprezentowanie NBP w stosunkach prawnych z osobami trzecimi, wydawanie zarządzeń wewnętrznych, instrukcji i regulaminów oraz innych przepisów regulujących organizację i działalność NBP, powoływanie i odwoływanie członków Rady Naukowej, mającej charakter organu opiniodawczo-doradczego, oraz sprawowanie funkcji przewodniczącego nowej instytucji bankowej - Rady Banków (Kaszubski, 1995b, s. 15). Rada Banków miała być organem koordynacyjnym i konsultacyjnym banków. W jej skład wchodzili: Prezes NBP jako przewodniczący i reprezentant na zewnątrz oraz jego pierwszy zastępca, prezesi banków o zasięgu 
ogólnokrajowym oraz przedstawiciele: banków spółdzielczych, Komisji Planowania przy Radzie Ministrów i Ministra Finansów. Wykonywanie uchwał Rady powierzono Prezesowi NBP. Jak słusznie zauważa C. Kosikowski ,analizując skład, zadania i kompetencje Rady trudno nie oprzeć się wrażeniu, że jest to twór organizacyjny, pozwalający Prezesowi NBP objąć władzę w dziedzinie całego systemu bankowego i pieniężno-kredytowego oraz umożliwiający upozorowanie sprawowania tej władzy w sposób kolegialny" (Kosikowski, 1982, s. 147-148). Skład Zarządu NBP nie zmienił się znacznie w wyniku reformy - Prezes NBP, wiceprezes-pierwszy zastępca Prezesa NBP, wiceprezesi NBP oraz członkowie - jednak zmienił się sposób powoływania składu: wiceprezesów powoływał Prezes Rady Ministrów na wniosek Prezesa NBP, a pozostałych członków sam Prezes NBP. Do kompetencji Zarządu należało podejmowanie uchwał niezbędnych do wykonywania zadań NBP oraz rozpatrywanie wszystkich podstawowych zagadnień z zakresu działalności NBP, dotyczących m.in. planu kredytowego, bilansu przychodów i wydatków ludności, funkcjonowania systemu kredytowego i pieniężnego, polityki pieniężno-kredytowej i projektów podstawowych aktów normatywnych, przepisów dotyczących działalności NBP, gospodarki NBP, polityki kadrowej i płacowej NBP itd. Prezes NBP wydawał regulamin określający szczegółowy zakres $\mathrm{i}$ tryb działania Zarządu oraz tryb podejmowania uchwał. Uregulowanie to było wewnętrznie niespójne, ponieważ z jednej strony Zarząd był uprawniony w określonych sprawach do podejmowania uchwał, które powinny być wiążące dla Prezesa, z drugiej strony, to właśnie Prezes decydował o kształcie funkcjonowania Zarządu w wydanym przez siebie regulaminie (Gronkiewicz-Waltz, 1994, s. 103-104). Rozwiązania prawne zawarte w nowej ustawie o NBP uchwalonej w roku 1989 nie zmieniły w sposób istotny organizacji NBP oraz trybu powoływania i kompetencji poszczególnych organów: Prezesa, Zarządu i Rady Naukowej Utrzymano zasadę jednoosobowości w kierowaniu bankiem, wskazując prezesa NBP jako organ kierujący działalnością NBP.

\section{Prezes, Rada Polityki Pieniężnej i Zarząd - nowy trójpodział władzy}

Uchwalenie Konstytucji RP z dnia 2 kwietnia 1997 r. oraz wejście w życie nowej ustawy o NBP z dnia 29 sierpnia 1997 r. w istotny sposób zmieniło organizację polskiego banku centralnego oraz kompetencje poszczególnych organów banku. Sposób tych regulacji i kształt przyjętych 
przez ustawodawcę rozwiązań znacząco odbiega od wcześniejszych rozwiązań. W miejsce jednoosobowego kierownictwa dokonał się faktyczny trójpodział władzy: za wyodrębnieniem trzech organów - Prezesa, Rady Polityki Pieniężnej oraz Zarządu (art. 227 ust. 2 Konstytucji RP oraz art. 6 ustawy o NBP) - podążyła dekoncentracja kompetencji.

Prezes NBP powoływany jest przez Sejm bezwzględną większością głosów na wniosek Prezydenta RP na 6-letnią kadencję, licząc od dnia powzięcia uchwały o jego powołaniu. Wniosek prezydenta do Sejmu o powołanie Prezesa Narodowego Banku Polskiego nie jest obostrzony wymogiem podpisu Prezesa Rady Ministrów (art. 144 Konstytucji). Ta sama osoba nie może być Prezesem NBP dłużej, aniżeli przez dwie kolejne kadencje. Oznacza to, że po przerwie trwającej chociażby jedną kadencję można ponownie być powołanym na to stanowisko. Konstytucja zakazuje Prezesowi NBP przynależności do partii politycznej, związku zawodowego oraz prowadzenia działalności publicznej nie dającej się pogodzić z godnością jego urzędu. Prezesa NBP w czasie jego nieobecności zastępuje wiceprezes NBP, pierwszy zastępca Prezesa NBP. Prezes NBP ponosi odpowiedzialność konstytucyjną przed Trybunałem Stanu za naruszenie Konstytucji lub ustawy, w związku z zajmowanym stanowiskiem lub w zakresie swojego urzędowania zgodnie z art. 198 Konstytucji. Uchwała Sejmu o pociagnięciu do odpowiedzialności konstytucyjnej Prezesa NBP powoduje zawieszenie go w czynnościach.

Konstytucja RP nie wypowiada się na temat odwołania Prezesa NBP, co niektórzy uznają za wyraz trwałości piastowania tego urzędu przez całą jego kadencję i brak możliwości odwołania go w trakcie jej trwania. Ustawa o NBP doskonale uzupełnia te luki. I tak odwołanie Prezesa NBP $\mathrm{z}$ funkcji $\mathrm{w}$ trakcie kadencji może nastąpić jedynie na skutek złożenia przez niego rezygnacji oraz w ustawowo określonych przypadkach, gdy:

- nie wypełnia on swoich obowiązków na skutek długotrwałej choroby;

- został skazany prawomocnym wyrokiem sądu za popełnione przestępstwo;

- złożył on niezgodne z prawdą oświadczenie lustracyjne, stwierdzone prawomocnym orzeczeniem sądu;

- Trybunał Stanu orzekł wobec niego zakaz zajmowania kierowniczych stanowisk lub pełnienia funkcji związanych ze szczególną odpowiedzialnością w organach państwowych.

W tych wypadkach wniosek o odwołanie Prezesa NBP powinien być przedstawiony Sejmowi przez Prezydenta RP, chociaż teza ta nie wynika wprost z żadnego przepisu prawnego. Co interesujące w przyjętych przez 
Konstytucję RP rozwiązaniach widoczny jest wpływ standardów europejskich oraz polskiej praktyki. Standardy europejskie wymagają bowiem, aby kadencja Prezesa narodowego banku centralnego wynosiła nie mniej niż 5 lat, a możliwość jego odwołania była ściśle określona w ustawie (Kłosiewicz, Szpringer, 1997 cyt. za Kosikowski, 1999, s. 278).

Ustawa o NBP przewiduje wygaśnięcie kadencji Prezesa NBP po upływie okresu sześcioletniego, w razie śmierci, w razie złożenia rezygnacji lub w razie odwołania. Mimo wygaśnięcia kadencji z powodu upływu okresu sześcioletniego Prezes NBP pełni obowiązki do czasu objęcia obowiązków przez nowego Prezesa NBP. W przypadku wygaśnięcia kadencji na skutek trzech pozostałych przyczyn to wiceprezes NBP - pierwszy zastępca Prezesa NBP przejmuje obowiązki Prezesa NBP do czasu objęcia obowiązków przez nowego Prezesa NBP. Ustawa nie określa, komu Prezes NBP może złożyć rezygnacje z pełnienia stanowiska. Wydaje się, że wchodzi tutaj w grę jedynie Sejm, który powołuje Prezesa NBP, nie zaś Prezydent RP, który w tej sprawie składa jedynie wniosek Sejmowi (Kosikowski, 1999, s. 278-279).

Prezes NBP jest przełożonym wszystkich pracowników Narodowego Banku Polskiego, do których odnoszą się przepisy Kodeksu pracy i przepisy o pragmatyce służbowej urzędników państwowych. Prezes reprezentuje NBP na zewnątrz, reprezentuje interesy Rzeczypospolitej Polskiej w międzynarodowych instytucjach bankowych oraz, o ile Rada Ministrów nie postanowi inaczej, w międzynarodowych instytucjach finansowych. W zakresie stosunków z władzami państwowymi obowiązki Prezesa NBP mają charakter formalno-reprezentacyjny, i tak:

- może uczestniczyć w posiedzeniach Sejmu;

- w imieniu RPP przedstawia Sejmowi i Radzie Ministrów informacje o bilansie płatniczym i międzynarodowej pozycji inwestycyjnej;

- w imieniu RPP przekazuje Radzie Ministrów i Ministrowi Finansów projekty założeń polityki pieniężnej, opinii w sprawie projektu ustawy budżetowej, prognozy bilansu płatniczego.

W ramach nadzoru finansowego Prezes NBP (lub delegowany przez niego Wiceprezes NBP) pełni funkcję członka Komisji Nadzoru Finansowego ${ }^{2}$

2 Komisja Nadzoru Finansowego jest centralnym organem administracji państwowej powołanym na mocy ustawy z dnia 21 lipca 2006 r. o nadzorze nad rynkiem finansowym. Komisja jest organem właściwym w sprawach nadzoru nad rynkiem finansowym. Do głównych zadań Komisji Nadzoru Finansowego należy sprawowanie nadzoru nad sektorem bankowym, rynkiem kapitałowym, ubezpieczeniowym i eme- 
oraz jest członkiem Komitetu Stabilności Finansowej ${ }^{3}$. W zakresie emisji znaków pieniężnych, Prezes NBP posiada duży pakiet uprawnień: ustala w drodze zarządzenia wzory i wartość nominalną banknotów oraz wzory, wartość nominalną, stop, próbę i masę monet oraz wielkość emisji znaków pieniężnych, jak również terminy wprowadzenia ich do obiegu. Również Prezes NBP może wycofywać z obiegu określone znaki pieniężne. Po upływie terminu określonego przez prezesa znaki te przestają być prawnym środkiem płatniczym na obszarze Rzeczypospolitej Polskiej i podlegają wymianie w wyznaczonych przez Prezesa NBP bankach. Prezes NBP określa, w drodze zarządzenia, szczegółowe zasady i tryb wymiany znaków pieniężnych zużytych lub uszkodzonych, które przestają być prawnym środkiem płatniczym na obszarze Rzeczypospolitej Polskiej oraz zasady i tryb postępowania przy zatrzymywaniu znaków pieniężnych (podejrzanych co do autentyczności) oraz postępowania z fałszywymi znakami pieniężnymi. Zarządzenie takie jednak wymaga uzgodnienia z Ministrem Sprawiedliwości i ministrem właściwym do spraw wewnętrznych. Prezes NBP ustala, w porozumieniu z ministrem właściwym do spraw wewnętrznych, zasady przechowywania wartości pieniężnych w bankach i przedsiębiorstwach produkujących znaki pieniężne oraz transportowania tych wartości przez banki i te przedsiębiorstwa.

W obszarze realizacji funkcji z zakresu polityki pieniężnej Prezes NBP wykonuje głównie uprawnienia związane z jego funkcją jako Przewodniczącego Rady Polityki Pieniężnej. Obwieszcza ustalone przez Radę stopy: dyskontowe i redyskontowe weksli, oprocentowania kredytu refinansowego i kredytu lombardowego oraz rezerw obowiązkowych. Ostatnim uprawnieniem, a raczej obowiązkiem Prezesa NBP zawartym w ustawie o banku centralnym, jest konieczność przedstawienia w ciągu 5 miesięcy od zakończenia roku budżetowego Sejmowi rocznego sprawozdania z działalności NBP.

Porównując uprawnienia i pozycję Prezesa NBP w nowej ustawie o NBP do wcześniej obowiązujących rozwiązań można dojść do wniosku,

rytalnym, nadzór nad instytucjami płatniczymi i biurami usług płatniczych oraz nad instytucjami pieniądza elektronicznego.

3 Komitet Stabilności Finansowej został powołany na mocy ustawy z dnia 7 listopada 2008 roku. Celem działania Komitetu jest zapewnienie efektywnej współpracy w zakresie wspierania i utrzymania stabilności krajowego systemu finansowego poprzez wymianę informacji, opinii i ocen sytuacji w systemie finansowym w kraju i za granicą oraz koordynację działań w tym zakresie. 
iż rzeczywiście znacznie ograniczono jego władzę. Obecnie przede wszystkim wynika ona $z$ kierowania organami NBP oraz funkcji reprezentacyjnych, choć trzeba pamiętać, iż w dalszym ciągu istnieją wyjątki w tym względzie, jak chociażby sprawa prowadzenia polityki emisyjnej (Niemierka, 1998, s. 9).

Utworzenie Rady Polityki Pieniężnej, jako nowego organu NBP, postrzegane było jako wyraz kompromisu politycznego i doktrynalnego w sprawie ustanowienia nadzoru nad działalnością banku centralnego. W wielu krajach znane są instytucje, usytuowane jednak poza bankiem centralnym, które w imieniu państwa sprawują kontrolę i nadzór nad działalnością banku centralnego w zakresie polityki pieniężnej. W Polsce również padały propozycje, aby w nowej Konstytucji RP zawrzeć przepis o utworzeniu Komisji Bankowej nadzorującej działalność NBP. Mimo iż nie została ona zrealizowana, utworzenie Rady Polityki Pieniężnej ograniczało jednoosobowe władztwo Prezesa NBP w sprawach polityki pieniężnej (Kosikowski, 1999, s. 283).

Rada Polityki Pieniężnej jest ciałem kolegialnym. Tworzą ją Prezes NBP (jako przewodniczący) oraz dziewięciu członków, powoływanych w równej liczbie przez Prezydenta RP, Sejm i Senat spośród specjalistów z zakresu finansów. Kadencja członków Rady trwa 6 lat, przy czym funkcję członka Rady można pełnić tylko jeden raz. Powołanie nowych członków Rady przez organy do tego uprawnione powinno nastąpić najpóźniej do dnia wygaśnięcia kadencji poprzednich. Możliwość skrócenia kadencji jest ściśle limitowana. Art. 13 ust. 5 ustawy o NBP stanowi, że organy uprawnione do powołania członka Rady mogą go odwołać przed upływem sześcioletniego okresu wyłącznie w następujących przypadkach:

- zrzeczenia się swej funkcji;

- choroby trwale uniemożliwiającej sprawowanie funkcji;

- skazania prawomocnym wyrokiem sądu za popełnienie przestępstwa;

- złożenia niezgodnego z prawdą oświadczenia lustracyjnego, stwierdzonego prawomocnym orzeczeniem sądu;

- niezawieszenia działalności w partii politycznej lub związku zawodowym na okres kadencji w Radzie.

Ponadto kadencja członka wygasa w razie jego śmierci. O wygaśnięciu mandatu stwierdza organ powołujący. Uzupełnienia składu Rady na wolne miejsce $\mathrm{z}$ powodów wymienionych powyżej, dokonują organy powołujące. Organy na podjęcie decyzji mają nieprzekraczalny termin 3 miesięcy od odwołania lub stwierdzenia wygaśnięcia mandatu członka 
Rady ${ }^{4}$. Członkowie Rady w okresie kadencji nie mogą zajmować żadnych innych stanowisk i podejmować działalności zarobkowej lub publicznej poza pracą naukową, dydaktyczną lub twórczością autorską. Za zgodą Rady wyrażoną w drodze uchwały (bez udziału zainteresowanego) dopuszczalna jest działalność członka Rady w organizacjach międzynarodowych.

W myśl artykułu 227 ust. 6 Konstytucji RP oraz artykułu 12 ustawy o NBP najważniejszym zadaniem Rady jest ustalanie corocznie założeń polityki pieniężnej. Założenia te RPP ma obowiązek przedkładać do wiadomości Sejmowi równocześnie z przedłożeniem przez Radę Ministrów projektu ustawy budżetowej. Rada ma również obowiązek składania Sejmowi sprawozdania z wykonania założeń polityki pieniężnej w ciągu 5 miesięcy od zakończenia roku budżetowego ${ }^{5}$.

Ustęp 2 artykułu 12 ustawy o NBP nakłada na Radę bardziej szczegółowe zadania. Rada kierując się założeniami polityki pieniężnej w szczególności:

1) ustala wysokość stóp procentowych NBP;

2) ustala stopy rezerwy obowiązkowej banków i wysokość jej oprocentowania;

3) określa górne granice zobowiązań wynikających z zaciagania przez NBP pożyczek i kredytów w zagranicznych instytucjach bankowych i finansowych;

4) zatwierdza plan finansowy NBP oraz sprawozdanie z działalności NBP;

5) przyjmuje roczne sprawozdanie finansowe NBP;

6) ustala zasady operacji otwartego rynku.

4 Trybunał Konstytucyjny w wyroku z dnia 24.11.2003 roku (K 26/03) orzekł, że art. 13 ust. 7 zdanie drugie ustawy z dnia 29 sierpnia 1997 r. o NBP stanowiący, iż członek Rady powołany celem uzupełnienia miejsca w RPP opróżnionego wskutek odwołania lub stwierdzenia wygaśnięcia mandatu członka Rady, pełni swoje funkcje do końca kadencji, na którą powołany był jego poprzednik oraz art. 13 ust. 8 tejże ustawy w części jakiej przewiduje możliwość ponownego powołania do Rady Polityki Pieniężnej jeżeli poprzednie powołanie nastąpiło w trakcie kadencji na okres krótszy niż 3 lata, są niezgodne z art. 227 ust. 5 Konstytucji Rzeczypospolitej Polskiej, z wyłączeniem skutków powołania dokonanego przed wejściem w życie tego wyroku. W uzasadnieniu TK przyjmuje, że art. 227 ust. 5 Konstytucji należy odczytywać jako statuujący 6-letnią kadencję indywidualną poszczególnych osób wchodzących w skład Rady Polityki Pieniężnej.

Jest to istotna zmiana w procesie kreowania polityki pieniężnej w stosunku do stanu sprzed 1998 r., w którym projekt założeń NBP w zakresie polityki pieniężnej Prezes NBP przedkładał Sejmowi, a Sejm te założenia uchwalał. 
W ramach swoich kompetencji Rada Polityki Pieniężnej dokonuje ocen działalności Zarządu NBP w zakresie realizacji założeń polityki pieniężnej oraz określa zasady rachunkowości NBP, wzór bilansu, rachunku zysków i strat oraz zawartość informacji dodatkowej.

Analiza przepisów Konstytucji i ustawy o NBP z 1997 roku pozwala zauważyć pewne ciekawostki legislacyjne. Nie do końca jasny jest charakter zadań RPP. Z ogólnych przepisów Konstytucji i ustawy wynika, że Rada ma się zajmować ustalaniem i nadzorowaniem realizacji polityki pieniężnej, natomiast wśród szczegółowych zadań, które Rada ma realizować, kierując się ustalonymi przez siebie założeniami tej polityki, znajdujemy m.in. zatwierdzanie planu finansowego NBP i sprawozdania z działalności NBP, przyjmowanie rocznego sprawozdania finansowego NBP oraz określanie zasad rachunkowości NBP. Wnioskując ustawodawca nie do końca mógł się zdecydować, czy Rada w swojej działalności ma się skupiać na polityce pieniężnej, czy też nadzorować politykę finansową NBP. Wydaje się, że połączenie kompetencji kreacyjnych z nadzorczymi może nie wyjść na dobre jakości wykonywania obu tych rodzajów zadań (Niemierka, 1998, s. 8). Niewątpliwym jednak jest fakt, iż obecność w strukturze organizacyjnej NBP Rady Polityki Pieniężnej wpływa na zwiększenie niezależności funkcjonalnej banku centralnego w zakresie zasad tworzenia, realizacji i odpowiedzialności za wykonywanie polityki pieniężnej. NBP realizuje bowiem przede wszystkim politykę pieniężną zgodnie z coroczną uchwałą Rady, będącej organem banku centralnego, a nie ciałem w stosunku do niego ,zewnętrznym”. Z drugiej strony ustawa o NBP - nieprecyzującej merytorycznej zawartości przedmiotowej uchwały - daje w praktyce możliwość, by RPP każdego roku samodzielnie decydowała o rodzaju, a zwłaszcza o stopniu szczegółowości zadań, o których planowanej realizacji poinformuje Sejm i inne organy państwowe (Jończyk, 1998, s. 34).

Trzecim konstytucyjnym organem NBP jest Zarząd, w skład którego wchodzą Prezes NBP - jako przewodniczący oraz 6-8 członków Zarządu, w tym 2 wiceprezesów NBP. Członków Zarządu powołuje na okres 6 lat i odwołuje Prezydent Rzeczypospolitej Polskiej na wniosek Prezesa NBP. Ta sama osoba nie może być członkiem Zarządu dłużej niż przez dwie kolejne kadencje. Powołanie nowych członków Zarządu powinno nastąić najpóźniej do dnia wygaśnięcia kadencji poprzednich. Odwołanie członka Zarządu przed upływem sześcioletniego okresu może wyłącznie nastąpić w przypadku:

- zrzeczenia się swej funkcji; 
- choroby trwale uniemożliwiającej sprawowanie funkcji;

- skazania prawomocnym wyrokiem sądu za popełnienie przestępstwa;

- złożenia niezgodnego z prawdą oświadczenia lustracyjnego, stwierdzonego prawomocnym orzeczeniem sądu;

- niezawieszenia działalności w partii politycznej lub związku zawodowego na okres kadencji w Zarządzie.

W razie śmierci członka Zarządu, organ powołujący stwierdza wygaśnięcie jego mandatu. Uzupełnienia składu Zarządu na wolne miejsce z przyczyn określonych powyżej, Prezydent RP dokonuje nie później niż w okresie 3 miesięcy od odwołania lub stwierdzenia wygaśnięcia mandatu członka Zarządu. Przepisy ustawy wymagają, by członek Zarządu nie zajmował żadnych innych stanowisk i nie podejmował działalności zarobkowej lub publicznej poza pracą naukową, dydaktyczną lub twórczością autorską. Członek Zarządu będący członkiem partii politycznej lub związku zawodowego obowiązany jest na okres kadencji w Zarządzie zawiesić działalność w tej partii lub w tym związku, pod rygorem odwołania z Zarządu.

Zarząd NBP ma charakter organu wykonawczo-zarządzającego, na co wskazują podstawowe jego zadania, mianowicie: realizacja uchwał RPP oraz kierowanie działalnością NBP. Do zakresu działania Zarządu NBP należy m.in.: realizowanie zadań z zakresu polityki kursowej; okresowa ocena obiegu pieniężnego i rozliczeń pieniężnych oraz obrotu dewizowego; nadzorowanie operacji otwartego rynku; ocena funkcjonowania systemu bankowego; analiza stabilności krajowego systemu finansowego; uchwalanie planu działalności i planu finansowego NBP; uchwalanie prowizji i opłat bankowych stosowanych przez NBP oraz ustalanie ich wysokości; określanie zasad gospodarowania funduszami NBP; określanie zasad organizacji i podziału zadań w NBP; określanie zasad polityki kadrowej i płacowej w NBP; uchwalanie rocznego sprawozdania z działalności NBP; sporządzanie rocznego sprawozdania finansowego NBP; opracowywanie bilansów obrotów płatniczych państwa z zagranicą; przygotowywanie i rozpatrywanie projektów uchwał i innych materiałów kierowanych do Rady. Zarząd podejmuje uchwały w sprawach niezastrzeżonych w ustawie do wyłącznej kompetencji innych organów NBP, niezbędnych do zapewnienia realizacji zadań i sprawnego funkcjonowania NBP. Uchwały Zarządu podejmowane są większością bezwzględną głosów, a w przypadku równej liczby głosów rozstrzyga głos Prezesa.

Analizując obecnie obowiązujące przepisy dotyczące wyboru organów NBP, szczególnie Prezesa i Rady Polityki Pieniężnej, nie sposób nie 
zauważyć znaczącego wpływu pozostałych instytucji ustroju politycznego na ten akt. Prezydent oraz Sejm i Senat aktywnie uczestniczą w wyborze Prezesa NBP oraz członków Rady Polityki Pieniężnej. Jedynym podmiotem niezaangażowanym bezpośrednio w proces wyboru jest drugi człon egzekutywy - Rada Ministrów. Biorąc jednak pod uwagę zasady funkcjonującego w Polsce systemu parlamentarno-gabinetowego, partie reprezentowane w rządzie swój wpływ na wybór omawianych organów mogą realizować poprzez reprezentacje w Sejmie bądź Senacie. Służąca zagwarantowaniu apolityczności organów NBP ich dość długa, 6-letnia kadencja, zapewnia ciągłość i autonomię funkcjonowania banku centralnego niezależnie od zmieniającej się rzeczywistości politycznej. Znaczącym rozwiązaniem ustrojowym jest fakt braku odpowiedzialności RPP i Zarządu za podejmowane decyzje. Jedynie Prezes NBP, który przewodniczy obu tym organom, jest podmiotem ponoszącym odpowiedzialność. Jak słusznie zauważa Cezary Kosikowski, możliwa jest jednak sytuacja, gdy Rada bądź Zarząd podejmą uchwały wbrew stanowisku Prezesa NBP, który następnie poniesie odpowiedzialność za decyzje, z którymi się nie zgadza (Kosikowski, 1999, s. 286, 288).

\section{Ewolucja funkcji i zadań Narodowego Banku Polskiego}

Narodowy Bank Polski jako bank państwowy swoją działalność w 1945 r. rozpoczął od wypełniania podstawowych funkcji skoncentrowanych na działalności emisyjnej oraz ochronie waluty, by w kolejnych latach stopniowo poszerzać zakres swoich kompetencji (por. Jezierski, Leszczyńska, 1996, s. 18-20, 55). Reformy okresu 1948-1952 doprowadziły do ukształtowania struktury zgodnej z modelem organizacji bankowości w gospodarce socjalistycznej. Model ów, uformowany w ZSRR na początku lat 30., charakteryzował się koncentracją czynności bankowych, polegających na wydzieleniu kilku banków o określonym profilu i zakresie funkcji, czyniąc je monopolistami w relacjach z obsługiwanymi przez nie podmiotami. Ustawa o NBP z 2 grudnia 1958 r. regulowała wszelkie zmiany, jakie zaszły w działalności NBP w latach 1945-1957 oraz określała relacje z władzami rządowymi. Najistotniejszym przepisem była zasada, że bank realizuje politykę pieniężno-kredytową państwa zgodnie z wytycznymi Ministerstwa Finansów. Zgodnie ze statutem zatwierdzonym przez Radę Ministrów 10 listopada 1959 r. zakres kompetencji NBP wyrażał się między innymi w czynnościach: bezpośredniego kredytowa- 
nia jednostek gospodarki narodowej, emitowania znaków pieniężnych, organizowania, przeprowadzania i kontrolowania rozliczeń pieniężnych w gospodarce, organizowania i dokonywania obrotu wartościami dewizowymi, kasowej i rozliczeniowej obsługi budżetu państwa i współdziałanie w kontroli jego wykonywania, kontrolowanie działalności finansowej jednostek gospodarki narodowej. Ustawa z 2 grudnia 1958 r. utrwalała pozycję NBP jako centralnej instytucji emisyjnej, kredytowej, rozliczeniowej i dewizowej oraz organu państwowego współdziałającego z całym aparatem administracyjnym $\mathrm{w}$ realizacji polityki gospodarczej (Jezierski, Leszczyńska, 2001, s. 47, 52-54). Do 1981 r. system bankowy w Polsce nie był wyodrębnionym sektorem w gospodarce - banki stanowiły część resortu finansów. System bankowy składał się z monobanku - Narodowego Banku Polskiego, który był centralnym bankiem państwa oraz centralną instytucją kredytową, oszczędnościową, rozliczeniową i dewizową koordynującą działalność pieniężno-kredytową oraz kontrolującą jej realizację oraz trzech wyspecjalizowanych banków ogólnokrajowych: Banku Handlowego SA obsługującego prawie cały handel zagraniczny Polski, Banku Polska Kasa Opieki SA obsługującego operacje dewizowe ludności oraz Banku Gospodarki Żywnościowej działającego w sektorze rolniczym. Wraz ze zmianą ustroju gospodarczego zarówno system bankowy, jak i pozycja banku centralnego musiały ulec zasadniczym przekształceniom (Wyczański, Gołajewska, 1996, s. 11-12). Głównym celem reform przeprowadzonych w 1982 r. (ustawy Prawo Bankowe i o statucie NBP z dnia 26 lutego 1982 r.) było zmniejszenie zależności NBP od Rady Ministrów i Ministra Finansów. W efekcie NBP oraz pozostałe banki zostały wyodrębnione ze struktury Ministerstwa Finansów. Bank centralny formalnie uzyskał pewną samodzielność, składając sprawozdanie ze swej działalności w Sejmie. Jednocześnie NBP zaczął pełnić kierowniczą rolę w stosunku do pozostałych banków (Polański, 1995, s. 51-52). Uregulowania przyjęte w wyniku kolejnych reform zawarte w ustawie Prawo bankowe i ustawie o NBP z dnia 31 stycznia 1989 r. przyniosły już fundamentalne zmiany $\mathrm{w}$ postaci ukształtowania dwuszczeblowego systemu bankowego. Stworzenie dwupoziomowej organizacji bankowości oznaczało przede wszystkim rozdzielenie funkcji emisyjnej i kredytowej wykonywanych dotychczas jednocześnie przez NBP - „monobank”. Wyłączone z NBP oddziały operacyjne prowadzące działalność depozytowo-kredytową były bazą dla zorganizowania niezależnych banków komercyjnych. NBP stał się bankiem centralnym i bankiem banków typowym dla gospodarki rynkowej, którego działalność miało na celu w szcze- 
gólności umacnianie waluty krajowej (Węcławski, 1995, s. 32-33; Baka, 1997, s. 29-34).

Efektem finalnym transformacji ustrojowej było określenie funkcji NBP w Konstytucji RP. Ustawa zasadnicza jako główną i podstawową funkcję NBP wskazuje wyłączne prawo emisji pieniądza oraz ustalania i realizowania polityki pieniężnej, jak również nakłada na niego odpowiedzialność za wartość polskiego pieniądza. Ustawa o NBP z 1997 r. dopełnia ten przepis obowiązkiem wspierania polityki gospodarczej rządu, ale tylko gdy nie ogranicza to podstawowego celu NBP. W świetle obecnych rozwiązań prawnych NBP jako bank centralny pełni trzy podstawowe funkcje: banku emisyjnego, banku banków oraz centralnego banku państwa. Jako bank emisyjny NBP ma wyłączne prawo emitowania znaków pieniężnych będących prawnym środkiem płatniczym w Polsce, określa wielkość ich emisji oraz moment wprowadzenia do obiegu, za którego płynność odpowiada. Bank organizuje obieg pieniężny i reguluje ilość pieniądza w obiegu. Wypełniając swoje zadania jako bank banków NBP pełni w stosunku do banków funkcje regulacyjne zapewniające bezpieczeństwo depozytów zgromadzonych w bankach oraz stabilność sektora bankowego. Wykonuje takie zadania jak: organizowanie systemu rozliczeń pieniężnych, prowadzenie bieżących rozrachunków międzybankowe czy uczestniczenie w międzybankowym rynku pieniężnym. Bank centralny odpowiada za stabilność i bezpieczeństwo całego systemu bankowego. NBP jako centralny bank państwa prowadzi obsługę bankową budżetu państwa, rachunki bankowe rządu i centralnych instytucji państwowych, państwowych funduszy celowych i państwowych jednostek budżetowych oraz realizuje ich zlecenia płatnicze (http://www.nbp.gov.pl/ home.aspx?f=/o_nbp/informacje/funkcje_banku_centralnego.html).

\section{Konkluzje}

W wyniku reform z 1997 roku zmianom uległa nie tylko struktura organizacyjna czy zakres funkcji, ale również zakres niezależności Narodowego Banku Polskiego. W okresie gospodarki centralnie sterowanej NBP nie miał żadnej autonomii w wypełnianiu swoich funkcji. Konstytucja RP oraz ustawa o NBP z 29 sierpnia 1997 r. wyposażyły polski bank centralny w uprawnienia, które sytuują go w gronie najbardziej niezależnych banków centralnych w świecie. Pozycja instytucjonalna NBP odpowiada obecnie najwyższym standardom. Zwrócić należy uwagę, iż nadanie 
obecnego kształtu niezależności banku było poprzedzone próbami ograniczenia jego autonomii w drodze propozycji zgłaszanych przez partie polityczne w czasie pracy nad projektem ustawy o NBP. Dotyczyły one m.in. zobowiązania do finansowania (do pewnego poziomu) deficytu budżetowego czy nakazu współpracy z agendami rządowymi w realizacji gospodarczej polityki państwa. Niezależność banku centralnego w Polsce uwidacznia się przede wszystkim w konstytucyjnym zakazie bezpośredniego finansowania przez bank deficytu budżetowego oraz zagwarantowaniu bankowi prawa do samodzielnego kształtowania i realizowania polityki pieniężnej. Narodowy Bank Polski zajmuje obecnie wysoką pozycję w strukturze organów państwa, a wpisanie go do ustawy zasadniczej zakończyło okres ewolucji, przeobrażeń i szukania najlepszego usytuowania dla polskiego banku centralnego.

\section{Bibliografia}

Baka W. (1997), Transformacja bankowości polskiej w latach 1988-1995, Zarządzanie i Finanse, Warszawa.

Dekret o Narodowym Banku Polskim z 15 stycznia 1945 roku, Dz. U. 1945, Nr 4, poz. 14.

Dekret o reformie bankowej z 25 października 1948 roku, Dz. U. 1948, Nr 52, poz. 412. Gronkiewicz-Waltz H. (1994), Bank centralny. Od gospodarki planowej do rynkowej, Olympus, Warszawa.

http://www.nbp.gov.pl/home.aspx?f=/o_nbp/informacje/funkcje_banku_centralnego.html, 15.06.2013.

Jezierski A., Leszczyńska C. (2001), Narodowy Bank Polski 1948-1970, Narodowy Bank Polski, Warszawa.

Jezierski A., Leszczyńska C. (1996), Pierwsze lata działalności Narodowego Banku Polskiego, Narodowy Bank Polski, Warszawa.

Jończyk A. (1998), Rada Polityki Pieniężnej - nowy organ banku centralnego, „Przegląd Podatkowy", nr 8.

Kaszubski R. W. (1995a), Narodowy Bank Polski - centralny organ państwa, „Glosa”, nr 10.

Kaszubski R. W. (1995b), Narodowy Bank Polski 1945-1988 - aspekt prawny, „Bank i Kredyt", nr 8.

Kłosiewicz P., Szpringer W. (1997), Zarzqdzanie Bankiem Centralnym w świetle nowej ustawy o Narodowym Banku Polskim, „Glosa”, nr 11.

Konstytucja Rzeczypospolitej Polskiej z dnia 2 kwietnia 1997 roku, Dz. U. 1997, Nr 78, poz. 483. 
Kosikowski C. (1982), Dyskusyjne problemy reformy systemu bankowego PRL, „Przegląd Ustawodawstwa Gospodarczego", nr 7.

Kosikowski C. (1997), Gospodarka i finanse publiczne w nowej Konstytucji, „Państwa i Prawo", nr 11-12.

Kosikowski C. (2002), Pozycja Narodowego Banku Polskiego i jego organów w prawie polskim, „Państwo i Prawo”, nr 11.

Kosikowski C. (1999), Publiczne prawo bankowe, Polskie Wydawnictwo Ekonomiczne, Warszawa.

Niemierka S. (1998), Pozycja Prezesa NBPw ,, ustawach bankowych”, „Glosa”, nr 8.

Orzeczenie Trybunału Konstytucyjnego z dnia 13 września 1990 roku, U. 4/90, poz. 10.

Polański Z. (1995), Pieniadz i system finansowy w Polsce. Lata 1982-1993, Wydawnictwo Naukowe PWN, Warszawa.

Uchwała Rady Ministrów w sprawie nadania statutu Narodowemu Bankowi Polskiemu z dnia 27 czerwca 1975 roku, M.P. 1975, Nr 23, poz. 143.

Ustawa o Narodowym Banku Polskim z dnia 29 sierpnia 1997 roku, Dz. U. 1997, Nr 140, poz. 938.

Ustawa o Narodowym Banku Polskim z 31 stycznia 1989 roku, Dz. U. 1989, Nr 4, poz. 22.

Ustawa o Narodowym Banku Polskim z 2 grudnia 1958 roku, Dz. U. 1958, Nr 72, poz. 356.

Ustawa o statucie Narodowego Banku Polskiego z 26 lutego 1982 roku, Dz. U. 1982, $\mathrm{Nr} 7$, poz. 57.

Ustawa o zmianie przepisów o reformie bankowej z 22 marca 1951 r. o zmianie przepisów o reformie bankowej, Dz. U. 1951, Nr 18, poz. 143.

Ustawa Prawo bankowe z dnia 29 sierpnia 1997 roku, Dz. U. 1997, Nr 140, poz. 939.

Ustawa Prawo bankowe z 31 stycznia 1989 roku, Dz. U. 1989, Nr 4, poz. 21.

Ustawa Prawo bankowe z 26 lutego 1982 roku, Dz. U. 1982, Nr 7, poz. 56.

Ustawa Prawo bankowe z dnia 12 czerwca 1975 roku, Dz. U. 1975, Nr 20, poz. 108.

Węcławski J. (1995), Problemy transformacji systemu bankowego, w: Przemiany gospodarki rynkowej, red. T. Tokarzewski, Wydawnictwo Uniwersytetu Marii Curie-Skłodowskiej, Lublin.

Wyczański P., Gołajewska M. (1996), Polski system bankowy 1990-1995, Fundacja im. Friedricha Eberta, Warszawa.

Wyrok Trybunatu Konstytucyjnego z dnia 24 listopada 2003 r. sygn. akt K 26/03, Dz. U. 2003, Nr 209, poz. 2035.

Wyrok Trybunału Konstytucyjnego z 26 maja 1998 roku sygn. akt K. 17/98., Dz. U. 1998, Nr 67, poz. 446.

Zubik M. (2001), Narodowy Bank Polski (analiza konstytucyjno-ustrojowa), „Państwo i Prawo", nr 6. 


\title{
The National Bank of Poland and political transformation: legal status, organization, functions
}

\begin{abstract}
Summary
The central bank of a country is closely related to its economy, in particular to one aspect, namely monetary policy. The political transformation that began in Poland in the 1980s brought about changes to the political, social and economic system. The reality of a free market economy challenged the National Bank of Poland (NBP), creating conditions different to those of a centrally planned economy. The status, tasks and internal organization of the NBP, the central bank of Poland since 1945, evolved along the same lines as other elements of the state system. Modern legal solutions are based on the provisions of the Constitution of the Republic of Poland of April 2, 1997 and the Law on the National Bank of Poland of August 29, 1997. They give the central bank of Poland the status of one of the most independent central banks in the world. This is primarily illustrated by the constitutional ban on the bank's direct financing of the budget deficit and ensuring the bank's right to independently shaping and executing monetary policy. The ultimate result of the political transformation was the designation of the NBP's functions in the Constitution of Poland: the exclusive right to issue money, formulate and implement monetary policy, and to bear responsibility for the value of the Polish currency. The Law on the National Bank of Poland from 1997 complemented the above provisions with an obligation to support the economic policy of the government, provided that this does not restrict the fundamental goals of the Bank. Given the current legal solutions, the NBP as the central bank performs three fundamental functions: that of an issuing bank, the bank of banks, and the central bank of the state. The internal structure of the Bank has also been altered: one-man management has been replaced with an actual tripartite division of power vested to three organs: the President, the Monetary Policy Council and the Board, which has resulted in a deconcentration of power. At present, the NBP enjoys a high position in the structure of the organs of the state. Including it in the Constitution has concluded the period of evolution, transformation and seeking the best place for the Polish central bank.
\end{abstract}


